\title{
Sprawozdanie z prac w Archiwum Instytutu im. gen. Sikorskiego w Londynie w 2018 r.
}

W trakcie zeszłorocznego wyjazdu do Londynu (4 tygodnie, 3-28 września 2018 r.) kontynuowałem prace przy porządkowaniu materiałów archiwalnych. Zajmowałem się dalej wyłącznie aktami zidentyfikowanymi jako rozkazy. Po poprzednich wyjazdach pozostały jeszcze do opracowania rozkazy w części pudeł oznaczanych literami „Z”.

„Rozkazy” są osobnym działem zasobu. Jednostki wchodzące w jego skład oznaczane są literą „R” i kolejną cyfrą arabską. Przyjęto zasadę, że jednostkę stanowiły rozkazy $\mathrm{z}$ jednego roku, nawet jeżeli był to jeden dokument (wyjątek stanowiły rozkazy zachowane w formie np. zeszytu prowadzonego ciągle dłużej niż rok). Rozkazy normowały życie każdej jednostki czy struktury wojskowej (w zależności od jednostki mogło ich być kilka lub kilkanaście na rok, ale zdarzały się też i takie, które miały ponad 300 dokumentów).

Schemat prac był podobny jak w czasie poprzednich wyjazdów. Początkowo wydzielano i identyfikowano akta. Następnie konieczne było sprawdzenie, czy porządkowane rozkazy nie znajdują się już w zasobie. Jeżeli tak - akta pozbawiano elementów metalowych, układano, pakowano w obwoluty i spisywano jako dublet. W przypadku gdy rozkazów jeszcze nie było w zasobie, przygotowywano je do włączenia. Na początku, jak zawsze, usuwano $\mathrm{z}$ akt wszelkie metalowe elementy, następnie układano w kolejności według numerów poszczególnych rozkazów. Jednostki archiwalne formowano, przyjmując, że jeden rok to osobna jednostka. Finalnie sygnowano obwoluty, wpisywano do ewidencji i pakowano do pudeł. Zdarzało się, że istniejące jednostki musiały być uzupełnione o brakujące pojedyncze dokumenty. Wtedy dołączano odnalezione, brakujące dotychczas rozkazy do istniejącej już jednostki i oczywiście korygowano zapisy ewidencji. Jeżeli trzeba było włączyć do już zeskanowanej jednostki, formowano całkowicie nową jednostkę.

Łącznie w trakcie opisywanego wyjazdu udało się opracować i włączyć 90 j.a. (liczących 1,4 mb) - sygn. R.1893 do R.1982. Oprócz akt włączonych do zasobu, wyłączono dwa duże pudła dubletów (ok. $2 \mathrm{mb}$ ). Sprawdzone zostały wszystkie pudła oznaczone roboczo literą ,Z”. Po pracach z aktami pozostałe pudła zostały na nowo rozmieszczone w magazynach dla zapewnienia łatwiejszego do nich dostępu.

Z odnalezionych i włączonych rozkazów zwraca uwagę znaczna ilość dokumentów związanych z Polską Marynarką Wojenną (dalej: PMW). Z rozkazów poszczególnych okrętów odnalazły się rozkazy ORP „Wicher” z lat 1934-1939 (do maja), a więc obejmujące większą część służby tego okrętu (1930-1939). Był to jedyny kontrtorpedowiec, który nie został wysłany wraz z Dywizjonem Kontrtorpedowców do Wielkiej Brytanii w sierpniu 1939 r. ORP „Wicher” został 3 września zatopiony w porcie helskim. Porządkowane dokumenty to najprawdopodobniej egzemplarze przekazywane do Dowództwa Dywizjonu na ORP „Grom” lub na inny okręt Dywizjonu (OORP „Burza” i „Błyskawica”). Odnaleziono także rozkazy dla okrętów OORP „Wilja” i „Kujawiak”. Z okresu przedwojennego 
włączono rozkazy Komendy Portu Wojennego Gdynia (1929-1939) i Komendy Garnizonu Gdynia (1927-1936, 1938-1939), jak również rozkazy Dywizjonu Kontrtorpedowców (1938-1939) i Kadry Szeregowych Floty (1933, 1935). Zasób został także uzupełniony o rozkazy oddziałów i służb z okresu stacjonowania Marynarki Wojennej w Wielkiej Brytanii. W 1942 r. organizacyjnie struktury PMW podzielono na Komendy Morskie „Północ” (z siedzibą w Greenock) i „Południe” (z siedzibą w Plymouth). Częścią Plymouth jest baza Devonport i często to ta nazwa jest podawana jako siedziba niektórych polskich jednostek. Stacjonował tu jako pływające koszary, przejęty przez Marynarkę statek ORP „Gdynia”, eks-pasażerski „Kościuszko”. To na jego pokładzie lokowane były niektóre służby, których rozkazy były teraz porządkowane i włączane do zasobu. W toku tego wyjazdu odnaleziono i włączono do zasobu właśnie rozkazy Komendy Morskiej Południe z lat 1942-1947, a także mających tam siedzibę (Plymouth/Devonport): Stacji Zbornej (1944 r.), Komendy Uzupełnień Floty (1940-1947), Bazy Zaopatrzenia Marynarki Wojennej (1940-1947), Centrum Wyszkolenia Specjalistów Floty (1945-1947). Włączono też rozkazy Domu Wypoczynkowego Marynarki Wojennej w Brighton z lat 1942-1947.

Wszystkie rozkazy z nieopracowanych dotąd pudeł oznaczanych literami „Z” zostały już odnalezione i włączone bądź przesunięte do dubletów. W pudłach trzeba jeszcze sprawdzić zarządzenia Szefa Kierownictwa Marynarki Wojennej. Wprawdzie są już w zasobie, ale niekompletne, należy je zweryfikować i uzupełnić. Dodatkowo w pozostałych pudłach rozpoznano interesujące materiały, np. akta związane z ewakuacją żołnierzy z Rumunii do Francji, działalnością ambasad i konsulatów w Europie (m.in. listy więźniów obozu Miranda de Ebro), listy związane z rozmieszczeniem demobilizowanych żołnierzy i ich rodzin.

Mariusz Kluczewski

Archiwum Narodowe w Krakowie 